\title{
GÉNERO E IMAGEN DEL PODER EN LA HISTORIA CONTEMPORÁNEA ${ }^{1}$
}

\author{
Mónica Moreno Seco y Alicia Mira AbAd \\ Universidad de Alicante
}

\section{Introducción}

La historia de género, que tiene ya una importante trayectoria en nuestro país, ha incorporado las recientes aportaciones de la nueva historia cultural, concediendo una posición destacada a las representaciones, las adscripciones simbólicas y la construcción de identidades individuales y colectivas. En ese orden de cosas, las diversas culturas políticas que surgieron en la contemporaneidad elaboraron diversas imágenes del poder que adquirieron a su vez perfiles variados, dependiendo del contexto espacial en el que se desarrollaron (poder nacional, local, en el seno de diversos colectivos y movimientos) y del periodo histórico que las encuadró a lo largo de los siglos XIX y XX.

En este sentido, este monográfico de Feminismo/s propone una nueva mirada sobre la imagen y la representación pública del poder, desde una perspectiva de género. La feminidad y la masculinidad han sido elementos fundamentales en la construcción simbólica del poder, ya sea en torno a las monarquías, las formas de Estado republicanas -como recoge la imagen de la portada- o las naciones, ya sea por parte de diferentes corrientes políticas o sociales. Entre los diversos mecanismos de socialización la educación, por ejemplo, ha contribuido a que perduren o se cuestionen esas representaciones y ha influido en la construcción identitaria de ciudadanos y ciudadanas. Con el paso del tiempo, la introducción de nuevos elementos de representación, junto al mantenimiento de los tradicionales ha puesto de relieve la existencia

1. El presente monográfico se inscribe en el marco del proyecto HAR2008-04389/HIST del Ministerio de Ciencia e Innovación.

Feminismo/s 16, diciembre 2010, pp. 9-12 
de discordancias, pero también la necesidad de combinar elementos del pasado con imágenes modernas que implicaron una evolución en las atribuciones simbólicas de género.

Otro elemento destacado de reflexión que aflora con la lectura de los artículos que ahora presentamos es la contradicción entre la asignación del poder a la masculinidad y la presencia de mujeres, reales o imaginadas, en espacios de poder. Mujeres ideales que simbolizan las naciones o los valores que sustentan el poder; mujeres que ejercen el poder desde el trono, los gabinetes de gobierno o los ayuntamientos y que a la vez tienen una fuerte proyección simbólica sobre sus conciudadanas. Las respuestas, debates y soluciones a esta paradoja permiten realizar análisis muy sugerentes sobre la permanencia de los discursos tradicionales de género y las rupturas con los mismos.

Las autoras y autores que participan en este número de Feminismo/s ofrecen distintas aportaciones sobre estos aspectos. El primer artículo, firmado por Antonio J. Calvo Maturana y titulado «María Antonia de Borbón e Isabel de Braganza: el valor simbólico de las dos primeras mujeres de Fernando VII», establece una interesante relación entre representación de la monarquía y género a principios del siglo XIX, en que la imagen de dos reinas fue objeto de instrumentalización política entre defensores y detractores de Fernando VII. Los estereotipos de género formaron parte de diversos discursos en los que las reinas son descritas como conspiradoras o esposas virtuosas.

A medida que el liberalismo comenzó a afianzarse en la España del XIX, los símbolos y mitos nacionales cobraron importancia. Algunos fueron representados por mujeres, como analiza Marie-Angèle Orobon en «El cuerpo de la nación: alegorías y símbolos políticos en la España liberal (1808-1874)». Es un texto que examina el recurso al cuerpo femenino en diversas representaciones de la nación: desde la emancipación respecto a la monarquía durante la Guerra de la Independencia hasta la consolidación del liberalismo en la figura de Isabel II. Con el tiempo, el desarrollo de los nacionalismos periféricos propició que también se recurriese a elementos simbólicos femeninos. Es el caso del nacionalismo gallego, que encontró en la figura de Rosalía de Castro una representación idealizada de la madre-patria, como Encarna Alonso Valero desarrolla en su texto «'Madre Rosalía ruega por nosotros'. Género, mitos nacionales y literatura».

También las representaciones del poder fueron importantes en los mecanismos de socialización, como la educación. Con el artículo «Reformulando las imágenes del poder en torno a la domesticidad. La educación formal e informal como base de la ciudadanía femenina», Luz Sanfeliu propone un recorrido por las propuestas de feministas, de pedagogos y de republicanos para 
incorporar a las niñas y jóvenes al sistema educativo, poniendo en cuestión de esta manera las relaciones de poder entre mujeres y hombres en el siglo XIX y las primeras décadas del XX y contribuyendo a la ampliación de la ciudadanía femenina.

En las culturas políticas progresistas, la incorporación de las mujeres a los ámbitos de poder en condiciones de igualdad con los hombres se formula de manera teórica, pero no siempre se experimenta en la práctica. Así sucede en el socialismo, como formula Marta del Moral Vargas en el escrito titulado «En los márgenes del poder, en primera línea de las manifestaciones obreras: la representación de la militancia femenina en el Partido Socialista (19061927)». En él recoge la experiencia de trabajadoras militantes del PSOE, en los espacios de poder que ocuparon y el poder simbólico que alcanzaron a través de sus acciones colectivas.

Durante la dictadura de Primo de Rivera se desarrolló un destacado debate sobre la participación de las mujeres en la política, controversia que afectó a las atribuciones de la masculinidad y la feminidad. A pesar de la ausencia de mecanismos democráticos de acceso al poder, algunas mujeres fueron nombradas concejalas y alcaldesas, circunstancia que no era ajena a la demanda anterior del feminismo sufragista y que preparó el acceso pleno a la ciudadanía femenina en la Segunda República. Adriana Cases Sola ofrece sugerentes reflexiones en este sentido en su escrito «Del 'Ángel del Hogar' al 'Ángel del Ayuntamiento'. Mujeres e imagen del poder en Alicante (1923-1931)».

Más allá de las fronteras españolas, el artículo de Antonio Daniel Juan Rubio recoge la interesante trayectoria profesional de la primera mujer nombrada ministra en Estados Unidos, Frances Perkins, una figura muy poco conocida en nuestro país. En «Frances Perkins: A Life Of Commitment», el autor describe la relevante política laboral y social impulsada por esta gobernante, responsable de la cartera de Trabajo, como parte del programa del New Deal de Roosevelt. A pesar de las suspicacias que despertó su presencia en varios gobiernos, la ruptura simbólica que representó Perkins contribuyó a que se abrieran espacios de poder para las mujeres en su país.

Las representaciones del poder en las dictaduras y la extrema derecha de entreguerras han sido estudiadas en varios artículos. Uno de ellos reflexiona sobre la distancia entre la imagen que intentó proyectar el régimen fascista italiano sobre las mujeres y la realidad que vivieron las italianas. Se trata del texto de Carlota Coronado Ruiz, quien en «Mujeres en uniforme. Las organizaciones fascistas femeninas en los noticiarios cinematográficos Luce (19281943)» se sirve de esta destacada fuente documental al servicio del fascismo 
para mostrar la estrategia que el poder fascista desplegó con el objetivo de conseguir la adhesión femenina.

Regresando a España, Teresa María Ortega López, en «Hijas de Isabel. Discursos, representaciones y simbolizaciones de la mujer y de lo femenino en la extrema derecha española del periodo de entreguerras» analiza en profundidad los mitos elaborados por los intelectuales de extrema derecha, que utilizaron la idealización de la reina Isabel la católica para marcar las pautas de actuación femenina de las españolas. La dictadura franquista recurrió a la agrupación femenina del partido oficial FET y de las JONS, cuya simbología recogía muchos de los elementos anteriores, para encuadrar a las mujeres. Sofía Rodríguez López, en su escrito «La Sección Femenina, la imagen del poder y el discurso de la diferencia», señala las contradicciones entre la retórica falangista, que afirmaba incorporar a las mujeres al proyecto nacional e imperial franquista, y las diferencias que estableció en el acceso al poder entre mujeres y hombres, entre mandos y militantes o entre falangistas y contrarias a la dictadura.

La transición a la democracia española es la última etapa analizada en este monográfico. Una de las corrientes sociales y políticas más dinámicas del momento fue el feminismo, que ayudó a configurar una nueva identidad colectiva e incluso a construir un proyecto político y que recoge Vicenta Verdugo Martí en un texto titulado «Desmontando el patriarcado: prácticas políticas y lemas del movimiento feminista español en la transición democrática». Por su parte, Mercè Picornell en «¿De una España viril a una España travesti? Transgresión transgénero y subversión del poder franquista en la transición española hacia la democracia» realiza un original estudio centrado en el travestismo como símbolo de contrapoder que permitió en un determinado momento ejemplificar públicamente el final de la imagen de «virilidad» que había representado el poder franquista. 